\title{
NOVI VID USAVRŠAVANJA PROFESORÂ ENGLESKOG JEZIKA
}

Tatjana Glušac, Međusobno obučavanje kolega kao oblik usavršavanja profesorâ engleskog jezika, Biblioteka E-disertacija, Novi Sad: Filozofski fakultet, str. 270, 2016.

U vreme kada je stručno usavršavanje profesora engleskog jezika postalo imperativ usled potrebe da se kroz kontinuirani proces doživotnog učenja stalno usavršavaju njihove kompetencije i prate tehnološke inovacije koje će pomoći u uspešnom odvijanju nastave u učionici, a u zemlji u kojoj je institucionalna podrška stručnom usavršavanju manjkava a ponegde i nepostojeća, javila se potreba za pronalaženjem i primenom onih vidova usavršavanja koji će pomoći nastavnicima da na odgovarajući način reše probleme u nastavi i kvalitetno odgovore na izazove učenja u 21. veku.

Monografija pod naslovom Međusobno obučavanje kolega kao oblik usavršavanja profesorâ engleskog jezika Tatjane Glušac, docentkinje na Fakultetu za pravne i poslovne studije „Dr Lazar Vrkatić” u Novom Sadu, proistekla iz teksta doktorske disertacije odbranjene na Filozofskom fakultetu u Novom Sadu 2012. godine, predstavlja uspeo pokušaj da se popuni teorijska praznina u literaturi posvećenoj stručnom usavršavanju profesorâ engleskog jezika u Srbiji, kao i da rezultati istraživanja budu primenjivi u praksi koja je do sada bila manjkava $u$ pogledu dostupnosti ovog vida usavršavanja kod nas. S obzirom na to da, kako autorka kaže, uprkos postojećem zakonskom okviru koji bi trebalo da uređuje ovu oblast, kod nas još uvek nije uspostavljen valjan sistem stručnog usavršavanja u oblasti nastave engleskog jezika, neophodno je ,podržati profesore da udruženi sa kolegom ili celokupnim kolektivom pokušaju da nađu odgovor na pitanja koja imaju" (str. 13). Stoga je i glavni cilj monografije da predstavi novi vid usavršavanja koji ne zahteva velika sredstva, a može pomoći nastavnicima da kroz uzajamnu pomoć steknu neophodna znanja i veštine potrebne za rad u učionici.

Monografija je strukturisana na sledeći način: nakon kratkog Predgovora (str. 13-14) sledi poglavlje pod naslovom Uvodna razmatranja (str. 15-39) u kome autorka kontekstualizuje i detaljno obrazlaže značaj izabrane teme, defini- 
še pojam „stalnog stručnog usavršavanja”, te unutar postavljenog konteksta istraživanja navodi njegov predmet, ciljeve i hipoteze, uz opsežan pregled relevantne literature i dosadašnjih istraživanja u ovoj oblasti.

U drugom poglavlju, naslovljenom Stručno usavršavanje profesorâ engleskog jezika u Srbiji (str. 41-55), Tatjana Glušac se bavi trenutnim stanjem u Srbiji u pogledu zakonske regulative kojom se uređuje stručno usavršavanje nastavnika uopšte, a posebno nastavnika engleskog jezika. Navedene su postojeće mogućnosti za stručno usavršavanje profesorâ engleskog jezika u Srbiji, koje uključuju aktivnosti nekoliko institucija među kojima i Ministarstvo prosvete, nauke i tehnološkog razvoja, Zavod za unapređenje obrazovanja i vaspitanja (koji izdaje Katalog za stručno usavršavanje nastavnika, vaspitača i stručnih saradnika), kao i Britanski savet, ambasada Sjedinjenih Američkih Država u Beogradu, Udruženje nastavnika engleskog jezika Srbije (ELTA), inostrane izdavačke kuće i dr. Navedene su i prepreke kvalitetnom korišćenju postojećih mogućnosti usavršavanja među kojima su najčešće one finansijske prirode, kao i njihove manjkavosti poput nedovoljno precizno definisanih programa obuke, nezanimljivosti, višegodišnjeg ponavljanja istih seminara, neusklađenosti trajanja obuke sa obimom programa, nenavođenja jasnih ciljeva akreditovanih programa i precizno definisane ciljne grupe kojoj je program namenjen itd. Sve navedeno otežava učešće u programima i utiče na motivisanost nastavnika. Stoga se odluka o učešću veoma često donosi samo kao posledica obaveze da se sakupi propisani broj sati obaveznog stručnog usavršavanja. Poglavlje autorka monografije zaključuje rečima da ,[u] postojećoj situaciji stručno usavršavanje je tek izraz dobre volje i entuzijazma pojedinca, a time se ne obezbeđuje ni kvalitetno obavljanje posla, ni kvalitetno obrazovanje", čime definiše prazninu u dosadašnjem istraživanju i uvodi čitaoca u naredno, centralno poglavlje teorijskog opredeljenja.

Treće poglavlje monografije pod naslovom Predloženi model stalnog stručnog usavršavanja profesorâ engleskog jezika (str. 57-71) pruža čitaocu teorijske postavke modela međusobnog obučavanja kolega (eng. peer coaching). Nakon kratkog pregleda vrstâ obučavanja uopšte, sledi opsežan prikaz eksperimentalnog oblika stručnog usavršavanja profesorâ engleskog jezika, u kome autorka ističe značaj razlikovanja dva termina koja oba uključuju prisustvo kolega na času: 1. posmatranje ili nadgledanje (eng. supervision), koji podrazumeva prisustvo predstavnika uprave ili kolege na nastavi, bez vrednovanja prakse profesora, i 2 . vrednovanje ili evaluaciju (eng. evaluation), koji podrazumeva ,procenjivanje profesorove prakse i kompetencija zarad donošenja odluke o zaposlenom, npr. produžavanju ugovora i slično" (str. 60), čiji cilj može biti „procena uspešnosti profesorovog usavršavanja ili planiranje njegovog usavršavanja”, ali je njegov prvenstveni cilj donošenje suda o kvalitetu pedagoške 
prakse i obavljanju ostalih dužnosti nastavnika. Naime, model kojim se autorka u monografiji bavi odnosi se na „neevaluativan proces” koji podrazumeva „da dvoje kolega imaju razvijen solidaran, kolegijalan odnos i da posmatraju časove jedan drugog radi međusobnih konsultacija, a ne radi procene načina rada." (str. 61). Dalje se autorka usredsređuje na vrste takvog načina obuke i na činioce koji mogu doprineti njegovoj uspešnoj primeni u praksi. Poglavlje se završava navođenjem prednosti i nedostataka ovakvog modela usavršavanja.

Ključno, četvrto poglavlje monografije, naslovljeno Empirijsko istraživanje međusobnog obučavanja kolega (str. 73-184), sadrži prikaz istraživanja čiji glavni cilj, prema rečima autorke, ,nije da umanji značaj i vrednost postojećih, akreditovanih oblika stručnog usavršavanja”, već da ,ispita da li se međusobno obučavanje može primeniti u našim uslovima rada i da li daje pozitivne rezultate" (str. 74). U istraživanju sprovedenom tokom školske 2009/2010. godine učestvovali su profesori engleskog jezika koji rade u osnovnim i srednjim školama u Novom Sadu (ukupno 10 profesora, odnosno 5 parova kolega), nakon što su izneli svoje stavove u pogledu onih aspekata koje bi želeli da poboljšaju, bilo da se tiču sopstvenog rada u učionici bilo rada, tj. procesa učenja, svojih đaka. Koristeći nekoliko metoda istraživanja (anketa, vođenje dnevnika, posmatranje, analiza sadržaja i dr.), a sve u cilju izbegavanja „,problema istraživačkog paradoksa” usled mogućnosti da prisustvo istraživača utiče na ponašanje ispitivanih parova profesorâ, autorka nam detaljno predstavlja saradnju u učionici između svakog od pet parova profesora, ukazujući na probleme sa kojima se svako od njih susreće, kao i načine na koje ih je moguće najefikasnije rešiti. Za svaki posmatrani par profesora navedeno je i njihove mišljenje o eksperimentalnom vidu stručnog usavršavanja kome su učestvovali, kao i lična zapažanja autorke o svakom paru profesora, u kojima navodi pozitivne rezultate saradnje, ali i teškoće i probleme na koje su učesnici u istraživanju nailazili pri saradnji.

Rezimirajući rezultate istraživanja, autorka iznosi svoje zaključke u odnosu na postavljene ciljeve istraživanja: (1) da se ispita primenjivost eksperimentalnog oblika usavršavanja i (2) da se ispita uticaj eksperimentalnog oblika usavršavanja na pedagošku praksu profesora, kao i na učenje učenika. U pogledu primenjivosti, rezultati ukazuju na to da svi učesnici u istraživanju (sa izuzetkom jednog profesora) smatraju međusobno obučavanje kolega korisnim i efikasnim oblikom stručnog usavršavanja, ali navode i prepreke njegovoj primeni među kojima su najvažnije nedostatak vremena usled složenosti organizacije obučavanja, moguća subjektivnost kolega i otpor promenama. Podaci prikupljeni u istraživanju ukazuju i na evidentan pomak u profesorskoj praksi, ne samo u pogledu uticaja ovakvog vida usavršavanja na rad profesorâ i učenje učenikâ, već i u pogledu uvođenja tehnoloških inovacija u nastavu, što je sve dovelo do pozitivnih ishoda koji se 
tiču rešavanja raznovrsnih problema i nedoumica, promene pedagoških uverenja, unapređenja kolegijalnih odnosa, razmene znanja i iskustava, izgradnje ličnog samopouzdanja profesorâ i podizanju svesti o ispravnosti ili manjkavosti sopstvene pedagoške prakse. Iako se autorka unekoliko ograđuje od mogućnosti uopštavanja rezultata s obzirom na to da su u istraživanju učestvovali veoma motivisani profesori koji i inače koriste raspoložive vidove usavršavanja, evidentno je da su rezultati ,podsticajni” i da ukazuju na to da je međusobno obučavanje kolega prikladan način stručnog usavršavanja u našoj sredini, bez obzira na uzrast i nivo znanja učenika, s jedne, te pedagoško iskustvo i praksu profesorâ, s druge strane.

Konačno, u šestom i poslednjem poglavlju pod naslovom Završna razmatranja (str. 185-200) autorka sumira ideje i zaključke iz prethodnih poglavlja i pruža konkretne predloge za unapređenje trenutne situacije u pogledu stručnog usavršavanja profesorâ engleskog jezika kod nas, koji su zasnovani na dobijenim rezultatima eksperimentalnog rada sa profesorima. Sledi spisak korišćene literature sa više od 150 bibliografskih jedinica, kao i 39 dodataka koji, između ostalog, sadrže upitnik o stručnom usavršavanju profesorâ engleskog jezika, upitnik o međusobnom obučavanju kolega namenjen učesnicima u istraživanju, autentične prikaze beležaka pri opservacijama, pedagoška uverenja pojedinačnih profesora itd.

U svetlu šire, ne naročito ohrabrujuće, situacije u obrazovanju uopšte u našoj zemlji, a shodno tome i u oblasti stručnog usavršavanja nastavnikâ engleskog jezika, monografija Tatjane Glušac predstavlja izuzetan doprinos poboljšanju postojećeg stanja u toj oblasti. Predočavajući svim zainteresovanima - a to su, pre svega, oni uključeni u složen proces organizovanja i realizacije nastave engleskog jezika - od prosvetnih vlasti, direktora škola, roditelja, i na kraju, ali po važnosti na samom početku ovog spiska, samih profesorâ na svim nivoima obrazovanja - jedan relativno lako sprovodljiv i finansijski nezahtevan vid stručnog usavršavanja, autorka je u potpunosti uspela da na naučno rigorozan i dokumentovan način oslobođen arbitrarnog zaključivanja ukaže na mogući model koji bi, ukoliko bude volje i motivacije, mogao da se institucionalizuje i postane sastavni deo programa unapređenja pedagoške prakse u Srbiji. Monografija će biti od izuzetne koristi i predavačima na anglističkim katedrama kao podsticajno štivo koje bi moglo uticati na osmišljavanje programa obučavanja budućih profesorâ engleskog jezika i značajno obogatiti literaturu iz metodike nastave stranih jezika na univerzitetskom nivou.

Nadežda Silaški

Univerzitet u Beogradu Ekonomski fakultet Beograd silaskin@sbb.rs 